\title{
Validity Analysis of Guided Inquiry Based on Mind Mapping Learning Model (Gi-Mm) to Increase High School Students' Critical Thinking Ability
}

\author{
Eska Perdanawati Kahar Putri (Corresponding author) \\ Chemistry study program, Faculty of Teacher Training and Education, Tadulako University, \\ City of Palu, Central Sulawesi, Indonesia \\ Tel: +62 821-9081-2800 E-mail: eskaperdanawatikaharputri@yahoo.com \\ Baharuddin Hamzah \\ Chemistry study program, Faculty of Teacher Training and Education, Tadulako University, \\ City of Palu, Central Sulawesi, Indonesia \\ Siti Nuryanti \\ Chemistry study program, Faculty of Teacher Training and Education, Tadulako University, \\ City of Palu, Central Sulawesi, Indonesia \\ Afadil \\ Chemistry study program, Faculty of Teacher Training and Education, Tadulako University, \\ City of Palu, Central Sulawesi, Indonesia
}

\section{Abstract}

This study aimed to obtain models and learning tools for the Mind Mapping (GI-MM) model. This study used Research and Development study which refers to the steps by Borg and Gall. The results showed that the results of the development of the GI-MM model and learning model were reliable to be used in high school chemistry learning of the reaction rate with the following results: The relevance of the GI-MM model of 81.27 (valid), the consistency of the GI-MM model pf 81.43 (valid), observation sheet of GI-MM model implementation of 1.00 (very valid), Learning Implementation Plan (RPP) of 3.33 (valid), Student Worksheet (LKPD) of 3.67 (very valid), student activity observation sheet of 0.95 (very valid), student questionnaire response pf 1.00 (very valid), rubric of students' critical thinking ability of 1.00 (very valid), and items of students' critical thinking ability test of 0.96 (very valid).

Keywords: Guided Inquiry Learning Model, Mind Mapping (GI-MM), Critical Thinking Ability, High School Students

DOI: $10.7176 / \mathrm{JEP} / 10-36-22$

Publication date: December $31^{\text {st }} 2019$

\section{INTRODUCTION}

Learning model is one of the important components that support the success of the learning process. The right learning model will have an impact on student success and the achievement of learning objectives. Learning model is a pattern that is used as a guide in planning the learning process in class, so the learning model is a design or pattern that is used as a guide in planning the learning process in class to create a supportive atmosphere so that students feel free to respond naturally and regularly, and learning objectives can be achieved well (Suprijono, 2012).

The selection of the right learning model becomes the thing that needs to be done, to fit the characteristics of students and the learning that will be carried out, so that it can support students' critical thinking skills. The learning model for training students to think critically must be problem-based because it can stimulate students in thinking, from finding data to drawing conclusions so students can take the point of learning activities (Shoimin, 2014). Various learning models have been used to improve students' critical thinking skills, one of which is the inquiry learning model.

Critical thinking skills in the science learning process provide appropriate direction in thinking to analyze the symptoms or phenomena that arise in understanding the subject matter. Critical thinking skills need to be developed in students because through critical thinking skills, students easily understand concepts, apply concepts to different situations, and are more sensitive to problems (Mairiska, et al., 2014). Students who have critical thinking skills don't just look for answers. Students will try to develop other possible answers based on analysis and information that has been obtained from a problem. Critical thinking is the process of reasoning about a problem to the complex stages of "why" and "how". Students need to improve critical thinking skills because many students fail to use reasoning properly in solving problems due to low thinking ability (Halpern, 1999). This is in line with Minister of Education and Culture Regulation No. 81 of 2013 on curriculum 
implementation which states that future competencies needed are communication skills, creative and critical thinking (Ministry of Education and Culture, 2013).

One of the subjects of natural science that is good for the application of inquiry learning models in improving critical thinking skills is chemistry. Chemistry learning aims to make students master chemical concepts and be able to apply these chemical concepts to solve problems in everyday life scientifically. One of the material discussed in chemistry subjects in high school is the reaction rate material whose application is often found in daily life. The inquiry learning model that will be developed is quided inquiry because guided inquiry is suitable to be applied in high school because it matches the characteristics of high school students who tend to be less independent and still need advice and cues from the teacher (Rokhmatika, et al, 2012). The development of guided inquiry learning models is by incorporating mind mapping strategies into the learning model so that it can equip students with the skills to store information received in long-term memory. Mind mapping is a technique of compiling notes to help students use their full brain potential optimally by combining the work of the left and right brains. Mind mapping facilitates the entry of information into the brain and to retrieve information from the brain. Mind mapping is the best technique in helping the brain's thinking process regularly because it uses graphical techniques derived from useful thinking to provide universal keys that open up the potential of the brain (Prayudi, 2008).

Based on the background of the problem above, the purpose of this study was to analyze the validity of the GI-MM learning model in improving students' critical thinking skills.

\section{METHOD AND MATERIAL}

The study used a type of developmental research with a model development design that refers to the steps of Borg and Gall (1983) which consists of three stages, namely preliminary studies, learning model development and product testing/implementation. However, in this study only reached the stage of developing learning models. This study developed a guided inquiry learning model based on mind mapping and learning tools which include Learning Implementation Plans (RPP), Student Worksheets (LKPD), observation sheets for the implementation of learning models, student activity observation sheets, student response questionnaires, and students critical thinking skills tests on the reaction rate material.

Interpretation of data to determine the validity categories of each aspect assessed from the guided inquiry learning model component based on mind mapping has several assessment criteria (Ratumanan and Laurens, 2003) as follows:

$$
\begin{array}{cc}
85 \% \leq \mathrm{VaM} \leq 100 \% & =\text { very valid } \\
70 \% \leq \mathrm{VaM} \leq 85 \% & =\text { valid } \\
55 \% \leq \mathrm{VaM} \leq 70 \% & =\text { fairly valid } \\
35 \leq \mathrm{VaM} \leq 55 \% & =\text { less valid } \\
20 \% \leq \mathrm{VaM} \leq 35 \% & =\text { invalid }
\end{array}
$$

$\mathrm{VaM}$ is the average result of expert assessment of learning models developed. The criteria used to decide that the guided inquiry learning model based on mind mapping has a good degree of validity if the Vam value is at the minimum valid criteria or $\mathrm{VaM} \geq 70 \%$.

The validity categories for each aspect assessed from the learning component are determined based on the following evaluation criteria:

$$
\begin{array}{cl}
3.5 \leq \mathrm{M} \leq 4 & =\text { Very valid } \\
2.5 \leq \mathrm{M} \leq 3.5 & =\text { Valid } \\
1.5 \leq \mathrm{M} \leq 2.5 & =\text { Fairly valid } \\
\mathrm{M}<15 & =\text { Invalid }
\end{array}
$$

$\mathrm{M}$ is the average result of expert assessment of learning models developed. The criteria used to decide that a good degree of validity is if the average expert assessment of each aspect is within the minimum valid criteria $\mathrm{M} \geq 2.5$.

After validity is calculated, the reliability of the GI-MM learning model assessment sheet and its tools is calculated by using the percentage of agreements adapted from Colton \& Covert (2007) as follows:

Description:

$$
\text { percentage of agreements }(\mathrm{R})=\frac{\text { Agrements }(\mathrm{A})}{\text { Disagrement }(\mathrm{D})+\text { Agrements }(\mathrm{Al})} \times 100 \%
$$

A $=$ the number of matches between experts

$\mathrm{D}=$ the number of mismatches between experts

$\mathrm{R}=$ reliability coefficient of instrument

The percentage of agreements formula above is modified to the reliability formula:

$R=\frac{d(A)}{d(A)+d(D)}$ 
Description:

$\mathrm{R}=$ Reliability coefficient

$\mathrm{d}(\mathrm{A}) \quad=$ Average degree of agreement from the expert

$\mathrm{d}(\mathrm{D}) \quad=$ Average degree of agreement from the expert

The instrument has a high positive agreement from the expert if the reliability value $(R) \geq 0.70$.

\section{Results and Discussion}

The assessment of model books with content validation sheets aimed to obtain recommendations that are reliable to use (LD), reliable to use with improvements (LDP), or not reliable to use (TLD). Data on the relevance and consistency of the GI-MM model were analyzed through the calculation of the average value of each aspect provided by the expert through the assessment sheet.

Table 1 Results of expert assessment on GI-MM model relevance

\begin{tabular}{|l|c|c|}
\hline \multicolumn{1}{|c|}{ Assessment Aspect } & Average Percentage of Assessment & Category \\
\hline Obejective & 85.71 & Very valid \\
\hline Supporting Theory & 82.29 & Valid \\
\hline Learning Syntax & 79.29 & Valid \\
\hline Learning Environment & 81.91 & Valid \\
\hline $\begin{array}{l}\text { General Conclusions of } \\
\text { Validation }\end{array}$ & 77.14 & Valid \\
\hline
\end{tabular}

Based on the expert assessment of GI-MM model relevance in Table 1 can be described as follows: (1) the developed GI-MM model has a relevance with valid and very valid categories for all aspects assessed, this shows that the design of the GI-MM model has been in accordance with the four characteristics of the learning model, (2) the relevance of the GI-MM model in general has a very valid category, this shows that the components of the GI-MM model have been based on a strong theory and are suitable for use in learning.

In addition to assessing relevance, the seven experts also assessed the consistency of the GI-MM model. The purpose of consistency measurement is to obtain LD, LDP, or TLD recommendations of the GI-MM model.

Table 2 Results of expert assessment on GI-MM model consistency

\begin{tabular}{|l|c|c|}
\hline \multicolumn{1}{|c|}{ Assessment Aspect } & Average Percentage of Assessment & Category \\
\hline $\begin{array}{l}\text { The stages of the model with the } \\
\text { objectives to be achieved are not } \\
\text { contradictory. }\end{array}$ & 74.29 & Valid \\
\hline $\begin{array}{l}\text { The interrelations of supporting theories } \\
\text { and chemical characteristics support each } \\
\text { other. }\end{array}$ & & Valid \\
\hline $\begin{array}{l}\text { Understanding of supporting theories with } \\
\text { objective and chemical characteristics is } \\
\text { not contradictory. }\end{array}$ & 82.86 & Valid \\
\hline $\begin{array}{l}\text { The relationship between guided inquiry } \\
\text { models based on mind mapping internally } \\
\text { supports the activities of teachers and } \\
\text { students at each stage of learning. }\end{array}$ & & Valid \\
\hline $\begin{array}{l}\text { Teacher and student activities at each } \\
\text { stage of learning in the guided inquiry } \\
\text { model based on mind mapping are } \\
\text { interrelated. }\end{array}$ & & Very valid \\
\hline $\begin{array}{l}\text { The use of learning resources supports the } \\
\text { achievement of goals. }\end{array}$ & & Very valid \\
\hline $\begin{array}{l}\text { The patterns of interaction between } \\
\text { teachers and students support each other. }\end{array}$ & 88.57 & Very valid \\
\hline $\begin{array}{l}\text { Teacher behavior in increasing student } \\
\text { interest in learning is reflected in each } \\
\text { stage of learning. }\end{array}$ & 85.71 & Valid \\
\hline
\end{tabular}

Based on expert assessment of GI-MM model consistency in Table 2 shows that: (1) of the eight assessment aspects to determine the GI-MM model consistency, three aspects were declared very valid and five aspects were declared valid, (2) in general, GI-model MM consistency had a valid category, this shows that the 
interrelationships between the stages in syntax and components of the learning model were not contradictory and reliable to be used in learning.

The results of the expert assessment of the relevance and consistency of the GI-MM model were supported by recommendations from seven experts who stated that the GI-MM model was reliable to be used with improvements (LDP).

\section{Validation of GI-MM Model Tools}

The development and validation of the learning tools was carried out after the GI-MM model was declared valid and reliable by the expert team. The purpose of developing learning tools is to determine the practicality and effectiveness of the GI-MM model. The tools developed were in the form of Learning Implementation Plan (RPP), Student Worksheet (LKPD), observation sheet for the implementation of learning models, student activity observation sheet, student response questionnaire, and student critical thinking ability assessment sheet. The whole set of validations were carried out to determine whether it is reliable or not to be used in learning process.

\section{Results of Expert assessment on Tools to Assess the practicality of GI-MM model}

The tool used to assess the practicality of the GI-MM model is the observation sheet for the implementation of learning models. The observation sheet for the implementation of the GI-MM model contains assessment aspects of the implementation of the syntax in the RPP and the detail implementation in the LKPD. The results of the expert assessment of the tool are described as follows:

\section{a. Results of Expert assessment on observation sheet for the implementation of learning models}

The observation sheet for the implementation of the GI-MM model was validated by three experts using the assessment sheet. Analysis of the results of the assessment sheet was performed by calculating the average results of expert assessments for each aspect assessed.

Table 3 Results of Expert assessment on observation sheet for the implementation of the GI-MM model

\begin{tabular}{|c|c|c|}
\hline Assessment Aspect & Average of Expert assessment & Validity Category \\
\hline Guide & 1.00 & Very valid \\
\hline Content & 1.00 & Very valid \\
\hline Language & 1.00 & Very valid \\
\hline
\end{tabular}

Table 3 shows that all aspects assessed on the observation sheet for the implementation of the GI-MM model were in a very valid category. This shows that the observation sheet for the implementation of the GI-MM model was valid and can be used in learning activities. This result is also supported by recommendations from three experts who stated as LD and two experts stated as LDP.

\section{b. Results of Expert assessment on Learning Implementation Plan (RPP) of GI-MM Model}

The assessment of the RPP was carried out by three experts using the RPP assessment sheet on Reaction Rate material.

Table 4 Results of Expert assessment and Validity Category of Each Aspect on Learning Implementation Plan (RPP) of GI-MM Model

\begin{tabular}{|l|c|c|c|c|}
\hline \multirow{3}{*}{ Assessment Aspect } & \multicolumn{3}{|c|}{$\begin{array}{c}\text { Average Results of Expert assessment and Validity Category of } \\
\text { Each Aspect on Learning Implementation Plan (RPP) }\end{array}$} \\
\cline { 2 - 5 } & I & II & III & IV \\
\hline \multirow{2}{*}{ Objectives/ Indicator } & 3.00 & 3.00 & 3.00 & 3.00 \\
\cline { 2 - 5 } & Valid & Valid & Valid & Valid \\
\hline \multirow{2}{*}{ Material } & 3.25 & 3.25 & 3.25 & 3.17 \\
\hline Language & Valid & Valid & Valid & Valid \\
\cline { 2 - 5 } & 4.00 & 3.33 & 3.33 & 3.33 \\
\hline Time Allocation & Very valid & Valid & Valid & Valid \\
\cline { 2 - 5 } & 3.33 & 3.33 & 3.00 & 3.00 \\
\hline Learning Activities & Valid & Valid & Valid & Valid \\
\cline { 2 - 5 } & 3.04 & 2.93 & 2.93 & 2.93 \\
\hline
\end{tabular}

Table 4 shows that all aspects assessed in the RPP were in a very valid category, this shows that the RPP developed was valid and reliable to be used in the implementation of the GI-MM model. 


\section{c. Results of Expert Assessment on Student Worksheet (LKPD) of GI-MM model}

The GI-MM LKPD was validated by three experts using the LKPD assessment sheet on the Reaction Rate material. Determination of the validity category of LKPD used the same reference as determining the validity category of the RPP.

Table 5 Results of expert assessment on each aspect of GI-MM LKPD

\begin{tabular}{|l|c|c|c|c|}
\hline \multirow{3}{*}{ Assessment Aspect } & \multicolumn{4}{|c|}{ Average Results of Expert Assessment and Validity Category of } \\
& \multicolumn{4}{|c|}{ each aspect of LKPD } \\
\cline { 2 - 5 } & I & II & III & IV \\
\hline \multirow{2}{*}{ Guide } & 3.67 & 3.33 & 3.33 & 3.00 \\
\cline { 2 - 5 } & Very valid & Valid & Valid & Valid \\
\hline \multirow{2}{*}{ Objective } & 3.33 & 3.67 & 3.67 & 3.00 \\
\cline { 2 - 5 } & Valid & Very valid & Very valid & Valid \\
\hline Content & 3.11 & 3.39 & 3.33 & 3.28 \\
\cline { 2 - 5 } & Valid & VAlid & Valid & Valid \\
\hline
\end{tabular}

Table 5 shows that all aspects assessed in the LKPD were in a very valid category. This shows that all LKPD developed in the GI-MM model were valid and reliable to use.

\section{Results of Expert assessment on Tools to Assess the effectiveness of GI-MM model}

The tools used to assess the effectiveness of the GI-MM model are student activity observation sheets, student response questionnaires, and students' critical thinking skills test sheets on the Reaction Rate material.

\section{a. Results of Expert assessment on student activity observation sheets}

Student activity observation sheets in the implementation of the GI-MM model were validated by three experts using an assessment sheet. Analysis of the results of the assessment sheet was performed by calculating the average results of expert assessments for each aspect assessed in the student activity observation sheets.

Table 6 Results of Expert assessment on student activity observation sheets

\begin{tabular}{|l|c|c|}
\hline \multicolumn{1}{|c|}{ Assessment Aspect } & Average Results of Assessment & Validity Category \\
\hline Guide & 0.85 & Very valid \\
\hline Content & 1.00 & Very valid \\
\hline Language & 1.00 & Very valid \\
\hline
\end{tabular}

Table 6 shows that all aspects assessed in the student activity observation sheet were in the very valid category and percentage of agreement, $\mathrm{R}=0.95$ (the reliability category was in the high positive agreement). This shows that the observation sheet of student activity was valid and reliable to be used to assess student activity during the learning process with the GI-MM model. This result is supported by recommendations from three experts who stated as LD and two experts who stated as LDP.

Based on the results of the assessment, recommendations, and improvements, it can be stated that the student activity observation sheet was valid and reliable to be used to assess student activities in the learning process by using the GI-MM model.

\section{b. Results of Expert assessment on Student Response Questionnaire}

The student response questionnaire in the implementation of the GI-MM model was validated by three experts using an assessment sheet. Determination of the validity category of the student response questionnaire was the same as determining the validity category of the activity observation sheet.

Table 7 Results of expert assessment on Student Response Questionnaire of GI-MM model

\begin{tabular}{|l|c|c|}
\hline \multicolumn{1}{|c|}{ Assessment Aspect } & Average & Validity Category \\
\hline Guide & 1.00 & Very valid \\
\hline Content & 1.00 & Very valid \\
\hline Language & 1.00 & Very valid \\
\hline
\end{tabular}

Table 7 shows that all aspects assessed in the student response sheet were in the category of very valid validity and percentage of agreement, $\mathrm{R}=1.00$ (the reliability category was in the high positive agreement). This shows that the student response sheet was valid and reliable used to assess student responses during the learning process with the GI-MM model. This result was supported by recommendations from two experts who stated as LD and three experts who stated as LDP. Based on the results of the assessment, recommendations, and improvements, it can be stated that the student response questionnaire was valid and reliable to be used to assess student responses to learning activities with the GI-MM model. 


\section{c. Results of Expert assessment on students' critical thinking skills test sheets}

Students 'critical thinking skills are determined based on the rubric of students' critical thinking skills assessment.

Table 8 Results of Expert assessment on the rubric of students' critical thinking skills assessment of GI-MM model

\begin{tabular}{|c|c|c|}
\hline Assessment Aspect & Average Results of Assessment & Validity Category \\
\hline Content & 1.00 & Very valid \\
\hline Langauge & 1.00 & Very valid \\
\hline
\end{tabular}

Table 8 shows that all aspects assessed in the rubric for assessing students' critical thinking skills were in the very valid category and percentage of agreement, $\mathrm{R}=1.00$ (the reliability category was in the high positive agreement). This shows that the rubric for assessing students 'critical thinking skills was valid and reliable to be used to assess students' critical thinking skills during the learning process with the GI-MM model. This result was supported by recommendations from two experts who stated as LD and three experts who stated as LDP. Based on the results of the assessment, recommendations and improvements, it can be stated that the rubric of the students 'critical thinking ability assessment was valid and reliable to be used to assess students' critical thinking abilities towards learning activities by using the GI-MM model.

Table 9 Average Results of Expert Assessment and Validity Categories for Each Aspect in the Critical Thinking Ability Test

\begin{tabular}{|c|c|c|c|c|c|c|}
\hline \multirow{2}{*}{ No } & \multicolumn{7}{|c|}{ Criteria and Validity Category Assessment Aspect } \\
\cline { 2 - 7 } & Material & $\begin{array}{c}\text { Validity } \\
\text { Category }\end{array}$ & Construction & $\begin{array}{c}\text { Validity } \\
\text { Category }\end{array}$ & Language & Validity Category \\
\hline 1 & 1.00 & Very valid & 1.00 & Very valid & 1.00 & Very valid \\
\hline 2 & 1.00 & Very valid & 1.00 & Very valid & 1.00 & Very valid \\
\hline 3 & 1.00 & Very valid & 1.00 & Very valid & 1.00 & Very valid \\
\hline 4 & 1.00 & Very valid & 1.00 & Very valid & 1.00 & Very valid \\
\hline 5 & 1.00 & Very valid & 1.00 & Very valid & 1.00 & Very valid \\
\hline 6 & 1.00 & Very valid & 1.00 & Very valid & 1.00 & Very valid \\
\hline 7 & 1.00 & Very valid & 1.00 & Very valid & 1.00 & Very valid \\
\hline 8 & 0.92 & Very valid & 1.00 & Very valid & 1.00 & Very valid \\
\hline 9 & 0.92 & Very valid & 1.00 & Very valid & 1.00 & Very valid \\
\hline 10 & 0.92 & Very valid & 1.00 & Very valid & 1.00 & Very valid \\
\hline 11 & 1.00 & Very valid & 1.00 & Very valid & 1.00 & Very valid \\
\hline 12 & 1.00 & Very valid & 1.00 & Very valid & 1.00 & Very valid \\
\hline 13 & 1.00 & Very valid & 1.00 & Very valid & 1.00 & Very valid \\
\hline 14 & 1.00 & Very valid & 1.00 & Very valid & 1.00 & Very valid \\
\hline 15 & 1.00 & Very valid & 1.00 & Very valid & 1.00 & Very valid \\
\hline 16 & 1.00 & Very valid & 1.00 & Very valid & 1.00 & Very valid \\
\hline 17 & 0.92 & Very valid & 1.00 & Very valid & 1.00 & Very valid \\
\hline 18 & 1.00 & Very valid & 1.00 & Very valid & 1.00 & Very valid \\
\hline 19 & 1.00 & Very valid & 1.00 & Very valid & 1.00 & Very valid \\
\hline 20 & 1.00 & Very valid & 1.00 & Very valid & 1.00 & Very valid \\
\hline 21 & 1.00 & Very valid & 1.00 & Very valid & 1.00 & Very valid \\
\hline 22 & 1.00 & Very valid & 1.00 & Very valid & 1.00 & Very valid \\
\hline
\end{tabular}

Table 9 shows that all items of students' critical thinking ability tests had a very valid category in terms of material, construction, and language aspects. This shows that all test items were valid and reliable to be used to assess students' critical thinking skills with the GI-MM model.

Validation of the GI-MM model was carried out by an expert through a Focus Group Discussion (FGD) activity to assess the relevance and consistency of the learning model measured by using content and construct validation sheets. Based on expert assessment that the GI-MM model was valid in terms of relevance and consistency in accordance with the four characteristics of the learning model by Arends. That is, the GI-MM model was valid and can be trusted to obtain accurate data and can be applied in learning activities (Afadil, 2016). Model validation was performed separately with the validation of the GI-MM support model. That is, the validation of the learning tool used to determine the practicality and effectiveness of the model which was developed according to the learning model that has been declared valid by the expert. The validity of the GI-MM 
model and the tool showed valid as average results, the results indicated that the quality of the learning model as required by Nieveen (2007) had been met.

Model validation proposed by Nieveen (2007) must have relevance and consistency. The condition of a model had good relevance, if the components of the model are based on a strong theoretical rational, while the consistency of a model is good if the components of the model are not mutually contradictory internally. Both of these conditions have been fulfilled by the GI-MM model. Based on the description above, it shows that the GIMM model already has the characteristics that must be possessed, namely: 1) logical theoretical rational prepared by the designer, 2) the rationale of learning objectives to be achieved in learning, 3) teaching activities needed for effective model implementation, and 4) the learning environment needed to achieve the learning objectives. Therefore, it can be said that the four characteristics of the GI-MM model had characteristics as a learning model.

\section{CONCLUSION}

The GI-MM learning model and its learning tools had a very high validity category and were reliable to be implemented in learning.

\section{ACKNOWLEDGEMENT}

The author thanks the team of validators and fellow lecturers of the Science Education Doctoral program, University of Tadulako Postgraduate who helped in completing this research.

\section{Disclosure statement}

No potential conflict of interest was reported by the author.

\section{REFERENCES}

Afadil. 2016. Effectiveness of Learning Based Problem Solving with Aspect Ontolgy, Epistemology, Axiology to Increase Crtitical Thinking Ability and Understanding Thermochemical Concept of Students. Scientific Journal of Universitas Negeri Semarang. 1 (2): 66-74.

Borg, W. R., dan Gall, M. D. 1983. Education Research (An Introduction). Fourth Edition, New York \& London: Longman, Inc.

Colton, D. dan Covert, R. W. 2007. Designing and Concructing Instruments for Social Research and Evaluation. San Fransisco: Jossey-Bass.

Halpern, D. F. 1999. Teaching for Critical Thinking: Helping Collage Students Develop the Skills and Dispositions of a Critical Thinker. New Directions for Teaching and Learing. 80: 69-74.

Kementerian Pendidikan dan Kebudayaan. 2013. Modul Pelatihan Implementaasi Kurikulum 2013. Jakarta: Badan Pengembangan Sumber Daya Manusia Pendidikan dan Kebudayaan dan Penjaminan Mutu Pendidikan.

Mairisiska, T., Sutrisno dan Asrial. 2014. Pengembangan Perangkat Pembelajaran Berbasis TPACK pada Materi Sifat Koligatif Larutan untuk Meningkatkan Keterampilan Berpikir Kritis Siswa. Edu-Sains. 3 (1).

Nieveen, N. 2007. Formative Evaluation in Educational Design Research, In Akker, J., Bannan, B., Kelly, A., E., Nieveen, N., \& Plomp, T., "An Introduction to Education Design Research.” SLO. Netherlands Institute for Curriculum Development.

Prayudi. 2008. Mind mapping. Online:http://prayudi.wordpress.com/mind-mapping/. (diakses 10 Maret 2018).

Ratumanan, T. G. dan Laurens, T. 2003. Evaluasi Hasil Belajar: Relevan dengan Kurikulum Berbasis Kompetensi. Surabaya: Unesa University Press.

Rokhmatika, S., Harlita dan Prayitno, B.A. 2012. Pengaruh Model Inkuiri Terbimbing dipadu Kooperatif Jigsaw Terhadap Keterampilan Proses Sains Ditinjau dari Kemampuan Akademik. Jurnal Pendidikan Biologi. 4 (2): 72-83.

Shoimin, A. 2014. 68 Model Pembelajaran INOVATIF dalam Kurikulum 2013. Yogyakarta: AR-RUZZ MEDIA.

Suprijono, A. 2012. Metode dan Model-model Mengajar. Bandung: Alfabeta. 